\title{
A clinical study of metritis in dairy cows in the region of Batna (east of Algeria) and their treatments using different therapeutic protocols
}

\author{
Rahla Meziane ${ }^{1}$, Abdellatif Niar ${ }^{2}$, Mustapha Adnane Smadi ${ }^{3}$, Bakir Mamache $^{3}$, Toufik Meziane ${ }^{3}$ \\ $1 \&$ 3. Laboratory Environment, Health and Animal Production (ESPA). Institute of Agricultural and Veterinary Sciences. \\ University of Batna. Algeria; 2. Institute of Veterinary Science, University I bn Khaldoun, Tiaret.Algérie \\ Corresponding author: Rahla Meziane,email: rahbough77@yahoo.fr \\ Received: 17-05-2012, Accepted: 01-07-2012, Published online: 30-11-2012
}

How to cite this article: Meziane R, Niar A, Smadi MA, Mamache B and Mezianem T (2013) A clinical study of metritis in dairy cows in the region of Batna (Algeria) and their treatments using different therapeutic protocols, Vet World 6(1):45-48. doi: 10.5455/vetworld.2013.45-48

\begin{abstract}
Aim: The objective of this study was to make an inventory of cases of metritis in dairy cows during the post-partum period, to verify with a detailed clinical study on its real incidence in Batna region and to study the treatment of metritis, using different treatment protocols.
\end{abstract}

Materials and Methods: A total of 432 dairy cows were examined during the post partum period and forty dairy cows having metritis were selected and assigned into four groups of 10 each to be treated with different drugs. Visits were programmed to track the status of uterine involution and different parameters of fecundity and fertility of cows.

Result: The injection of Cloprostenol (a synthetic analogue of PGF2 $\alpha$ ) has a significant effect particularly on shorter intervals from calving to the first mating, calving to positive fertilization and for the reduction of the number of services of inseminations. Similarly, the association "antibiotic+Flunixin /Meglumine has a positive effect on the parameters mentioned above.

Conclusion: These results show that the double injection of Cloprostenol in the treatment of metritis improves the performance of fertility of animals and the dose of $3 \mathrm{ml}$ of PGF $2 \alpha$ had succeeded in giving a positive effect on the different fertility parameters studied, compared to the dose of $2 \mathrm{ml}$.

Key words : cow, fertility, metritis, PGF2 $\alpha$, postpartum.

\section{I ntroduction}

Metritis is a frequent pathology in Algerian dairy cows. Its multifactorial aetiology makes its prevention very difficult and unsuccessful in most cases $[1,2]$.

If metritis is not rapidly diagnosed and treated it would lead to infecondity, sterility and even premature reform of the cow (ex. third degree metritis). Therefore, the economic rentability of the herd would be affected seriously [3]. Delayed uterine involution and endometritis are generally the most common consequences of retained placenta; they are detrimental to the future breeding of the cow with altered parameters of fertility, thus causing a prolongation of the calving fertilizing insemination interval $[4,5]$.

There is a lot of controversy about appropriate treatment regimes for post calving uterine infections [6]. Studies on the treatment of subclinical endometritis with prostaglandin F2alpha or analogues, intrauterine antibiotics or proteolytic enzymes showed heterogeneous results [7-11].

The aim of this study is to determine the frequency of metritis, its overall impact on fertility, and efficacy of different therapeutic protocols for the treatment of metritic dairy cows in the region of Batna (East of Algeria). The use and study of efficacy of flunixine in the treatment of bovine metritis, represents one of the main objectives.

\section{Materials and Methods}

Study area: This study has been conducted in the region of Batna (East of Algeria) that is characterized by its sub tropical climate. The study lasted from March 2010 to February 2011.

Animals:

Clinical study of metritis cases in Batna region: The study has been conducted on a total of 432dairy cows during the post partum period in order to study the real frequency of metritis. The cows belong to 29 different herds covering different areas of Batna region.

Metritis treatment using different therapeutic protocols: Forty dairy cows among which $78 \%$ were multiparous and $22 \%$ were primiparous having metritis (any cow having a purulent vaginal discharge) were selected and randomly assigned into four groups of ten as follows:

Group I : 10 cows treated with oxytetracyclin intramuscularly according to their bodyweights.

Group II : 10 cows treated with oxytetracyclin intramuscularly and a single intramuscular injection of an anti inflammatory drug, the flunixin (Avlezan;Virbac) according to the manufacturer's recommendations.

Group III : 10 cows treated with prostaglandin F2 alpha (Estrumate; Schering plough) at a dosage of $2 \mathrm{ml}$ intramuscularly.

This group was subdivided into two groups of 5 cows each as follows : 
Table-1. Effect of the double injection of PGF2 on the clinical signs of metritis.

\begin{tabular}{|c|c|c|c|c|c|c|}
\hline Clinical examination of the genital tract & Group I & Group II & Single c & & Double inje & f PGF2 \\
\hline & $(n=10)$ & $(n=10)$ & $\begin{array}{l}\text { Group Illa } \\
(n=5)\end{array}$ & $\begin{array}{l}\text { Group IVa } \\
(n=5)\end{array}$ & $\begin{array}{l}\text { Group IIIb } \\
(n=5)\end{array}$ & $\begin{array}{l}\text { Group IVb } \\
(n=5)\end{array}$ \\
\hline No purulent vaginal discharge & $70 \%$ & $80 \%$ & $80 \%$ & $60 \%$ & $100 \%$ & $100 \%$ \\
\hline Pelvian uterine Position & $60 \%$ & $60 \%$ & $80 \%$ & $60 \%$ & $100 \%$ & $100 \%$ \\
\hline Uterine tonicity & $20 \%$ & $40 \%$ & $80 \%$ & $60 \%$ & $60 \%$ & $60 \%$ \\
\hline
\end{tabular}

Table-2. Effect of the different therapeutic protocols and the double PGF2 $\alpha$ injection on the fertility parameters in the studied cows.

\begin{tabular}{lccc}
\hline Groups & $\begin{array}{c}\text { Number of cows } \\
\text { (mean) }\end{array}$ & $\begin{array}{c}\text { Calving breeding } \\
\text { interval (mean) }\end{array}$ & $\begin{array}{c}\text { Calving breeding feconding } \\
\text { interval (mean) }\end{array}$ \\
\hline Group I & 10 & $163.22 \pm 89.08$ & $\begin{array}{c}\text { Number of breeding } \\
\text { (mean) }\end{array}$ \\
Group II & 10 & $105.62 \pm 39.66$ & $163 \pm 46.88$ \\
Group III & 10 & $105.33 \pm 37.82$ & $97.4 \pm 28.87$ \\
Group IV & 10 & $82.66 \pm 23.16$ & $112.37 \pm 37.51$ \\
Group IIIa, Group IVa & 10 & $86.8 \pm 26.5$ & $75.10 \pm 4.62$ \\
Group IIIb, Group IVb & 10 & $101.1 \pm 34.9$ & $97.10 \pm 34.4$ \\
\hline
\end{tabular}

- Group III(a): PgF2 $\alpha(2 \mathrm{ml}$ single dose).

- Group III(b): PgF2 $\alpha$ (2 ml double dose at 15 day interval).

Group IV: 10 cows treated with prostaglandin F2 alpha (Estrumate) at a dosage of $3 \mathrm{ml}$ by intramuscular route. This group was subdivided into two groups of 5 cows each as follows :

- Group IV (a): PgF2 $\alpha$ (3ml single dose )

- Group IV(b): PgF2 $\alpha$ (3ml double dose at 15 day interval).

The clinical follow-up comprises four visits in order to investigate the fertility parameters of the treated cows amongst others, the calving-first insemination interval, the calving-fecundity insemination interval, the number of services and the rate of pregnant cows( real fertility rate) 90 days after the start of treatment. The diagnosis of pregnancy was performed at 2 à 3 either using an echograph or a manual method respectively.

All the used methods in this work are conform to the regulations of International Animal Ethics Committee.

Statistical analysis: All the data were treated and analyzed using the Microsoft Excel. The statistical analysis was performed using the Student test (test t) with the Statistica and Minitab programs.

\section{Results}

The frequency of metritis reached a rate of $32.17 \%$ in Batna region.

The uterine involution was at 30 days post treatment. Appearance of the vaginal discharge: After treatment we noted that $20 \%$ of the group I cows (treated with oxytetracycline only) continued to present a purulent vaginal discharge while only $10 \%$ of group II cows excrete a vaginal discharge of the same appearance (treated with the combination oxytetracycline and flunixin). The same observation has been made in the group IV cows (treated with a single or a double injection of PgF2alpha) (Table-1).

Uterine position: This study has revealed that $60 \%$ only of the cows had a normal uterine involution in the group I and the group II compared to $90 \%$ and $80 \%$ to the cows treated with $\mathrm{PgF} 2 \alpha(2 \mathrm{cc})$ Group III(a) and those treated with PgF2 $\alpha$ (3cc) Group IV (b) respec- tively (Table-1).

Uterine tonicity: Only $20 \%$ of the cows had a tonic uterus in the group 1 compared to $70 \%$ and $60 \%$ in groups III and IV respectively and $40 \%$ in group II (Table-I).

Effect of the double injection of PgF2 $\alpha$ : The effect of the double injection of $\mathrm{PgF} 2 \alpha$ on the excretion of purulent vaginal discharge and on the fertility parameters was very significant .Indeed,70\% of the cows receiving a single injection of $\mathrm{PgF} 2 \alpha$ (Groups IIIa and IVa) against all the cows receiving the double injection of PgF2 $\alpha$ at 15 days interval(Groups IIIb and $\mathrm{IVb})$ had responded favorably to the treatment.

Effect of the dose of PgF2 $\alpha$ : The effects of the dose of $\mathrm{PgF} 2 \alpha$ on the fertility parameters were inconstant. The $2 \mathrm{cc}$ dose had a good effect on the uterine position and tonicity $(90 \%)$, whereas, the $3 \mathrm{cc}$ dose had a good effect on the elimination of purulent vaginal discharge $(80 \%)$.

\section{Follow- up of the fecundity}

Comparison of mating indices: The cows had a mean mating indices ranging from 2,22 $\pm 0,97$ and $1,3 \pm 0,48$ matings in groups I and II respectively and 1,1 $\pm 0,33$ matings for the groups III and IV(Table-2).

Comparison of the calving - first mating intervals: This study has revealed differences in the calving - first mating intervals particularly between the groups I and IV $(163,22, \pm 89,08$ Vs $82,66 \pm 23,16)$. However, this difference was not significant between the groups II and III $(105,62 \pm 39,66 \mathrm{Vs} 105,33 \pm 37,82)$ (Table-2).

Comparison of the calving - fecundity mating intervals: The results of the calving -fecundity mating intervals were $163 \pm 31,30 ; 97,4 \pm 19,3 ; 11, .37 \pm 33,1$ et $75,1 \pm 3,45$ days for cows of groups I, II,III and IV respectively. Reduction of the calving- fecundity mating interval by 65,6 days between the groups I and II , by 87,9 days between the groups I and III and by 37,27 days between the groups III and IV(Table-2) was observed.

\section{Discussion}

In the present study the frequency of acute and 
chronic metritis is $32,17 \%$. Hanzen et al., (1996) [12] had reported a frequency of the genital tract infection of $29 \%$ and $36 \%$ in dairy and beef cows respectively. In agreement with our observation ,Francoz (1970) [13] and Sheldon et al. (2009) [14] , stated that metritis is more frequent in primiparous cows than in multiparous ones, however, Miller et al., (1980) [15] reported contrary results.

The uterine involution is more rapid in primiparous cows than in multiparous ones, but cows that had vealed earlier had a better local immunity than that in heifers. In this category of age, the reduced of immunity may alter the benefic effect of the uterine involution. Dystocic vealings are more frequent in heifers than in multiparous cows. Therefore, they are more subjected to uterine infections and mainly to metritis. Aged multiparous cows, had showed a higher rate of frequency of uterine involution and therefore a higher frequency of metritis.

Thibier et al., (1988) [16] stated that the parity factor did not have a significant influence on the rate of metritis. However, Chaffaux et al., (1991) [17] and Santos et al., (2009) [18] reported that the parity did not appear to have a significant effect on the occurrence of metritis except in the primarous cows and those having calved at least five times before. This observation may be explained by the fact that heifers that are helped to calve are more exposed to infections.

The current study of fertility parameters showed that a significant difference between cows treated with Flunixin and those treated with oxytetracycline regarding the number of cows put in reproduction (AI. index). No significant difference was observed between cows treated with Flunixin and those treated with $\mathrm{PgF} 2 \alpha$. It is worthnoting that the use of Flunixin has given a very good AI index. These results are in contrast with those obtained by [19-22] who found that the best results were obtained by use of the double injection of $\mathrm{PgF} 2 \alpha$ at 15 day interval.

A significant difference had been noted between the groups I and III, the groups II and IV, the groups III (a) and IV(a) for the mean calving-fecundity breeding intervals parameter. For the same parameter, we observed the beneficial effect of the double injection of PGF2 $\alpha$ compared to the single injection of the same hormone. This finding confirms the results obtained by $[23,24]$. Our results are very close to those reported by Mami (1997) cited by [20] who found 153, 98 and 67 days for the groups I (control), II(single injection of PGF $2 \alpha$ ) and III (double injection of PGF2 $\alpha$ at 15 days interval).

\section{Conclusion}

This study revealed that:

-The Flunixin has the same effect as PGF $2 \alpha$ in cattle. Therefore, its use in the treatment of metritis will be of a great help.

-The injection of the 3cc dose of PGF2 $\alpha$ and double injection regimen had a better effect on fertility parameters compared to the $2 \mathrm{cc}$ dose of the same hormone. However, additional studies carried out on more important groups of cows are needed in order to have satisfactory data on the effect of the PGF $2 \alpha$ on the reproduction performances of cattle in the region.

\section{Author's contribution}

RM carried out the field study, AN has supervised all thesis work, TM is co-supervisor of RM. BM participated in writing and results analysis. MAS participated in the design of the study and statistical analysis of the results. All authors read and approved the final manuscript.

\section{Acknowledgements}

Great thanks for Dr Tainturier, Department of Pathology Reproduction, ONIRIS, National Veterinary School of Nantes and the Virbac Laboratories, France for providing us advises and the Flunixin in order to make this work. We also thank all the dairy farmers in the region of Batna (Algeria), for having opened the gates of their farms to carry out this research work perfectly.

\section{Competing interests}

Authors declare that they have no competing interest.

\section{References}

1. Niar A., Zidane K., Benchohra M., and Tainturier D. (2006) Evaluation of the effects of two protocols using Prostaglandin F $2 \alpha$ as a treatment of retained placenta in dairy cows in Algeria. Assiut. Vet. Med. J., $52: 343-352$.

2. Dubuc J., Duffield TF., Leslie KE., Walton JS., Leblanc SJ. (2011) Effects of postpartum uterine diseases on milk production and culling in dairy cows. J.Dairy Sci. 94(3):1339-46.

3. Zidane K., Niar A.,Tainturier D. (2011) Comparative effect on clinical use of PGF $2 \alpha$ and REPROCINE in the treatment of retained placenta in dairy cows at Tiaret region (Algeria). Asian Journal of animals and Veterinary Advances 6(6):593598.

4. Graves, W.M. and A.K. McLean, (2002) Solving post partum breeding problems. (UGA Bulletin No.1211). Cooperative Extension Services; University of Georgia, College of Agricultural and Environmental Sciences.

5. Melendez P., McHale J., Bartolome J., Archbald L.F., Donovan G.A. (2004) Uterine involution and fertility of Holstein cows subsequent to early postpartum PGF2 alpha. J. Dairy Sci. 87:3238-3246.

6. Currin J. (2010). Management and Prevention of Metritis. Extension Dairy Veterinarian, (540) 231-5838.

7. Lincke A., Drillich M., Heuwieser W. (2007) Subclinical endometritis in dairy cattle and its effect on fertility--a review of recent publications. Berl Munch Tierarztl Wochenschr.120(5-6):245-50.

8. Steffan J., Agric, M., Adriamanga, S., Thibier, M. (1984) Treatment of metritis with antibiotics or prostaglandin F2 alpha and influence of ovarian cyclicity in dairy cows. Am J Vet Res. Jun; 45(6):1090-4.

9. Dubuc, J., Duffield, TF., Leslie, KE., Walton, JS., Leblanc, SJ. (2011) Randomized clinical trial of antibiotic and prostaglandin treatments for uterine health and reproductive performance in dairy cows. J Dairy Sci. Mar; 94 (3): 132538.

10. Dolezel, R., Vecera M., Palenik T., Cech S., Vyskocil M. (2008) Systematic clinical examination of early postpartum 
cows and treatment of puerperal metritis did not have any beneficial effect on subsequent reproductive performance. Veterinarni Medicina, 53, 2008 (2): 59-69.

11. Galvão Klibs N. (2011) Identifying and Treating Uterine Disease in Dairy Cows. Proceedings $47^{\text {th }}$ Florida Dairy Production Conference, Gainesville, March 30.

12. Hanzen C., Houtain J.Y., Laurent Y. et coll. (1996) Effect of individual and herd factors on bovine reproduction performance. Ann. Méd. Vét.,140: 195-210.

13. Francoz G. (1970) Observation on the relationship between overfeeding and the incidence of metritis in cows after normal parturition. Refuah Vet., 27: 148-155.

14. Sheldon IM., Cronin J., Goetze L., Donofrio G., Schuberth HJ. (2009a) Defining postpartum uterine disease and the mechanisms of infection and immunity in the female reproductive tract in cattle. Biology of Reproduction 81, 1025-1032.

15. Miller H.V., Kimsey P., Kendrick J.W., Darien B., Doering L., Franti C., Horton J. (1980) Endometritis of dairy cattle : diagnosis, treatment, and fertility. Bovine Pract., 15: 13-23.

16. Thibier M., Steffan J. (1988) Metritis in the post-partum pathology in dairy cows. Epidemiology and cyclicity in Better knowing, understanding and mastering the bovine fecundity. Rev. French Soc. Buiatrics, 1: 157-183.

17. Chaffaux S., Lakhdissi H., Thibier M. (1991) Epidemiological and clinical study of post-puerperal endo- metritis in dairy cows. Rev. Méd. Vet., 167,3(4): 349-358.

18. Santos NR., Lamb DC., Brown DR., Gilbert RO. (2009) Postpartum endometrial cytology in beef cows. Theriogenology;71:739-745.

19. Drilich M.,Voigt D., Forderung D and Heuwieser W. (2007) Treatment of acute puerperal metritis with flunixin meglumine in addition to antibiotic treatment $J$. Dairy Sci; 90(8): 3758-63.

20. Zidane K. (2009) Incidence of uterine pathologies during the post-partum in cows in Tiaret region. Use of a treatment based on $\mathrm{PGF}_{2} \alpha$., Ph.D. Thesis, University Ibn Khaldoun, Tiaret ,101pp.

21. Cardin J. (2000) The usefulness of an injection of the PGF2 $\alpha$ analogous 15 days after calving to cows presenting retained placentas. Thèse Doct. Vét., Nantes $\mathrm{n}^{\circ} 074,73 \mathrm{pp}$.

22. Manspeaker, J.E. (2010) Metritis and Endometritis. Dairy Integrated Reproductive Management http://www.wvu. edu/ agexten/forglvst/Dairy/dirm22.pdf.

23. Galvão KN., Greco LF., Vilela JM., Sá Filho MF and Santos JEP. (2009a) Effect of intrauterine infusion of Ceftiofur on uterine health and fertility in dairy cows. $J$. Dairy Sci. 92:1532-1542.

24. Galvão KN., Frajblat M., Brittin SB., Butler WR., Guard CL and Gilbert RO.(2009b) Effect of prostaglandin F2alpha on subclinical endometritis and fertility in dairy cows. J. Dairy Sci. 92:4906-4913. 